\title{
THE LEVEL OF POLAND'S SOCIAL AND ECONOMIC DEVELOPMENT IN THE ASPECT OF THE EUROPEAN UNION'S INNER COHESION
}

\author{
by Rafat Willa
}

Each enlargement of the European Communities (EC) and later the European Union (EU) has had an indisputable influence on inner cohesion of the organization itself. The participants of the integration processes have included the countries deviating from the previous Member States by the level of the economic development, the structures of their economies, macroeconomic conditions, etc. This differentiation has taken its toll especially on the functioning and the expenses of common policies (mainly transfer ones) as well as the execution of the integration reinforcement plans such as the European Economic and Monetary Union. ${ }^{1}$ In this aspect the most serious consequences were caused by the admission of countries that were much weaker economically, especially Ireland, Greece, Spain and Portugal. These countries had to go through a long way of reforms in order to become rightful members of the organization and for their integration with the Communities to become a mutual success. A big part of the expenses connected with these reforms was financed by the

\footnotetext{
1 Compare: S. Płóciennik, Europejska integracja gospodarcza $w$ polityce RFN (1949-2000), Wrocław 2004, p. 313.
} 
common budget thanks to the structural funds and the Common Agricultural Policy. ${ }^{2}$

Also the enlargement of the European Union in 2004, this time eastward, which involved the admission of post-communist countries, by far fits the scenario mentioned above as all these countries expected, still expect but also need help of the EU. ${ }^{3}$ With the end of the Cold War era and the fall of the communism in the Central and Eastern Europe, the majority of the countries from that region declared a wish of an association and next entering the EU. As a result, it became clear that the Communities faced another challenge - - the strengthening of its inner cohesion so that the admission of the new countries would not be just a quantitative process but also the organization itself would not lose (but even gain) on its democracy and efficiency in action. ${ }^{4}$

In $1993^{5}$ a process, which resulted in the EU enlargement by 10 new countries, the 8 of which were from Central and Eastern Europe, began. ${ }^{6}$ However, even before this event, it was clear that despite the unprecedented

2 Compare: G. Denton, Budgetary needs of Eastern enlargement, [in:] Financial transfers of the European Union and Eastern enlargement, eds. A. Inotai, K. Vida, Budapest 1997, pp. 54-56.

3 Compare: Droga do jedności europejskiej. Fragment przemówienia Adenauera w Madrycie 16 lutego 1967 roku, [in:] Adenauer a Europa. Polityka europejska pierwszego kanclerza RFN (1949-1963), K. Ruchniewicz, Warszawa 2001, p. 92.

4 An interesting remark in this respect was made by Jim Hughes, Gwendolyn Sasse and Claire Gordon who claim that "in more than a decade since the fall of communism, the concept of Europe-building has been stretched by the pull of two policy agendas: firstly, a process of »deep integration « among a historical core group of EU states driven by the distilled notion of European exceptionalism; and secondly, a process of eastward enlargement EU membership driven by the diluted notion of "a wider Europe«", [in:] J. Hughes, G. Sasse, C. Gordon, The Regional Deficit in Eastward Enlargement of the European Union: Top Down Policies and Bottom Up Reactions, http://www.one-europe. ac.uk/pdf/w29gordon.pdf, p. 1.

5 The Author means the Council of Europe Summit in Copenhagen during which so called "Copenhagen criteria" for the candidate-countries were settled.

6 It was also important that Western Europe countries, especially the founders of the European Economic Community, "after 40 years of declarations, memoranda and appeals for the European unity, could not reject applications of eastern neighbours. That was a matter of the EU international credibility", [in:] S. Płóciennik, op.cit., p. 295. 
help of the EU for the candidate-countries (pre-accession funds: PHARE, ISPA, SAPARD), together with the borders enlargement there will be the increase of structural differentiation of the organization itself, which simultaneously will constitute a great challenge for its inner cohesion.

\section{THE ENLARGEMENT OF 2004 AND 2007 IN THE ASPECT OF THE EU COHESION}

The prospects of admission of new countries to Communities and at the same time the creation of the integration area, having at that time about 460 million citizens and being characterized by strong economy, worked in favour of the countries running for the EU membership. Fast developing markets of these countries had to be observed and appreciated as well. Nevertheless, it was in the economic sphere where a specific "catalogue" of factors came into being causing western fears of the consequences of such an integration.7 An extremely low level of national income, structural problems (unemployment, poor agriculture, inner inequalities of regions' development, regions being behind the EC level) or potential migration were emphasized, which in the long run might have caused destabilization in the EU itself or the paralysis of its policies.

Economies of many Central and Eastern European countries, which for many years functioned within the inefficient central planning, despite the financial help from the EU, the World Bank and other organizations are still characterized by a significant level of delay in comparison to an average level of EU states' economic development. An apt way of demon-

\footnotetext{
7 It should be reminded at this point that among former member states there were fears of potential eastward enlargement concerning institutional system paralysis, the weakness of democratic foundations of the countries running for the EU membership, an instrumental treatment of the EU as a guarantee of security, etc.
} 
strating this situation is the presentation of the EU Member States GDP criterion per head.

Table 1. GDP per head in 2008

(measured by purchasing power parity, (\%) - estimated data $)^{8}$

\begin{tabular}{|l|l|l|l|}
\hline Luxembourg & 261,3 & Italy & 98,9 \\
\hline Ireland & 143,6 & Greece & 96,5 \\
\hline the Netherlands & 133,8 & Cyprus & 92,9 \\
\hline Austria & 124,3 & Slovenia & 90,6 \\
\hline Sweden & 122,9 & the Czech Republic & 80,2 \\
\hline Denmark & 118,1 & Malta & 78,9 \\
\hline Belgium & 117,5 & Portugal & 75,3 \\
\hline Great Britain & 117,4 & Slovakia & 70,2 \\
\hline Germany & 115,8 & Estonia & 64,2 \\
\hline Finland & 114,8 & Hungary & 61,6 \\
\hline Euro Area & $109,7(2007)$ & Lithuania & 60,5 \\
\hline France & $109,1(2007)$ & Latvia & 55,2 \\
\hline Spain & 104,1 & Poland & 55,1 \\
\hline \multirow{2}{*}{ UE-27 } & 100,0 & Romania & 44,8 \\
\cline { 2 - 4 } & & Bulgaria & 39,7 \\
\hline
\end{tabular}

Source: Eurostat. ${ }^{9}$

Based on this table, one can conclude that there are significant economic differences in terms of national economies between the countries of "the old EU" and the new Member States. It should also be mentioned that the best prospering country from the post-communist EU members, Slovenia, reached in 2008 more than $90 \%$ of the EU average, which, of the

8 In the research there were other countries mentioned: Croatia - 62,7\%, Turkey $42,9 \%$ (the EU membership candidates); Island - 113,0\%, Norway - 174,6\%, Switzerland - 138,4\% (countries belonging to EFTA, forming together with the EU - the European Economic Area); the United States - 151,4\%; Japan - 110,4\%.

9 Eurostat: http://epp.eurostat.ec.europa.eu/tgm/table.do?tab=table\&init=1\&plugin $=1$ \&language $=$ en $\&$ pcode $=$ tsieb0 10 . 
EU-15, was better than only that of Portugal. It is clear that also among the countries that joined in 2004 (and later) there are differences in GDP. In these statistics, the countries which go off well are Cyprus and Slovenia; the worst in this respect seem to be Poland and the youngest EU members: Romania and Bulgaria. ${ }^{10}$

The above data clearly indicate that for many years the differentiations in terms of development of particular EU Member States will essentially shape the process of Europe unity. Just to provide an example, according to predictions by the Council of European Integration Committee, in order for Poland to reach $75 \%$ of the EU GDP average per head, it will have to develop at the pace of min. 4,4\% a year until the year of $2030 .{ }^{11}$

At this point it should be added that also other factors such as: the structure of economies of the Central and Eastern Europe countries, conditions of the job market and the level of payments (big unemployment rate), macro-economic situation of these countries (fiscal balance - the state of permissible budget deficit rates and public debt as well as the monetary balance in the context of the need for various economic reforms) will considerably contribute to a decline in EU inner cohesion. Despite this, the efforts of these countries to meet the EU demands should be appreciated. Thanks to them, in the long run, the countries will become the rightful members of the Economic and Monetary Union, for instance. ${ }^{12}$

\footnotetext{
${ }^{10}$ It is worth mentioning that accession of Bulgaria and Romania to the EU caused its area enlargement by $8,6 \%$, the population increased by $6,3 \%$ (both these statistics are similar to a situation when Austria, Finland and Sweden joined the EU). However, they added only $1 \%$ to GDP measured by the purchasing power parity, which was the weakest result in the history of the EU integration. What is more, their admission caused a drop in the GDP index per capita in the EU by $4 \%$.

Compare: Growing Regions, growing Europe. Fourth report on economic and social cohesion, Luxembourg 2007, p. 27.

11 Korzyści i koszty członkostwa Polski w Unii Europejskiej. Raport z badań, Warszawa 2003, p. 26. Compare.: A. Bołtromiuk, E. Magrel, Spójność społeczno-gospodarcza Unii Europejskiej jako podstawowy cel polityki strukturalnej, [in:] Regiony peryferyjne w perspektywie polityki strukturalnej Unii Europejskiej, ed. A. Bołtromiuk, Białystok 2003, p. 95.

12 After the last enlargement, the EU includes 27 countries and there are other sates "queuing"; all these countries represent not only different levels of economic development
} 


\section{POLAND'S SOCIO-ECONOMIC SITUATION IN COMPARISON WITH OTHER EUROPEAN UNION COUNTRIES}

It is without a doubt that Poland, in comparison with other western countries (and not only), is still behind in terms of its development. This is greatly due to Polish numerous structural problems which origins can be found in the country's history. The processes of industrial and agricultural restructurization as well as their slow privatization caused, beside positive effects, certain threats such as unemployment, low investment ability, little competitiveness of enterprises, ineffectiveness of the institutional system, etc. What is more, the problems and threats indicated above differ in terms of their intensity depending on particular voivodships (regions). Therefore, also "Poland's low socio-economic cohesion is a barrier itself in creating a larger European cohesion."13

Despite a stable but varied GDP growth rate, which can be observed since 1992, the difference between Poland and other European countries in terms of their development is still significant. ${ }^{14}$ In 2006, GDP reached $6,2 \%$ (not dated since 1997) and the economy once again started a dynamic development. It was confirmed by an even greater growth in 2007 and slightly smaller in 2008. The last phase of growth was observed between 1995-1997 when the average GDP growth rate reached 6,8\%. The next

but also non-identical economic interests connected with, for example, the amount of funds gained from Common Agricultural Policy or the structural funds. Equally relevant is the fact that they also have different if not sometimes opposing political interests and visions on the future of the integration process. This can have an influence on the future evolution of the organization together with the process of building the political union.

13 M. Nowicki (ed.), Polityka Spójności Unii Europejskiej w latach 2007-2013: Głos Polskich Regionów, Gdańsk 2002, p. 13. Compare: R. Petru, T. Laursen, Poland. Directions in Regional Policy, Warszawa 2004, pp. 46-56.

14 At the current development rate, the country will reach 75\% GDP per capita of the enlarged EU in the years 2025-2030. Compare: Projekt Narodowej Strategii Rozwoju Regionalnego na lata 2007-2013, zaakceptowany przez Radę Ministrów w dniu 6 września 2005 roku,

http://www.nsrr.gov.pl/NR/rdonlyres/F36C4DA8-A738-4BCA-BF37-45903AFDCACA/14584/nsrr_zwp72.pdf, p. 11. 
years were characterized by the economic downturn, which contributed to the fact that the growth rate dropped in 2001 to only $1,2 \%$.

Graph 1. GDP growth rate in Poland in the years of 1995-2008 (\%).

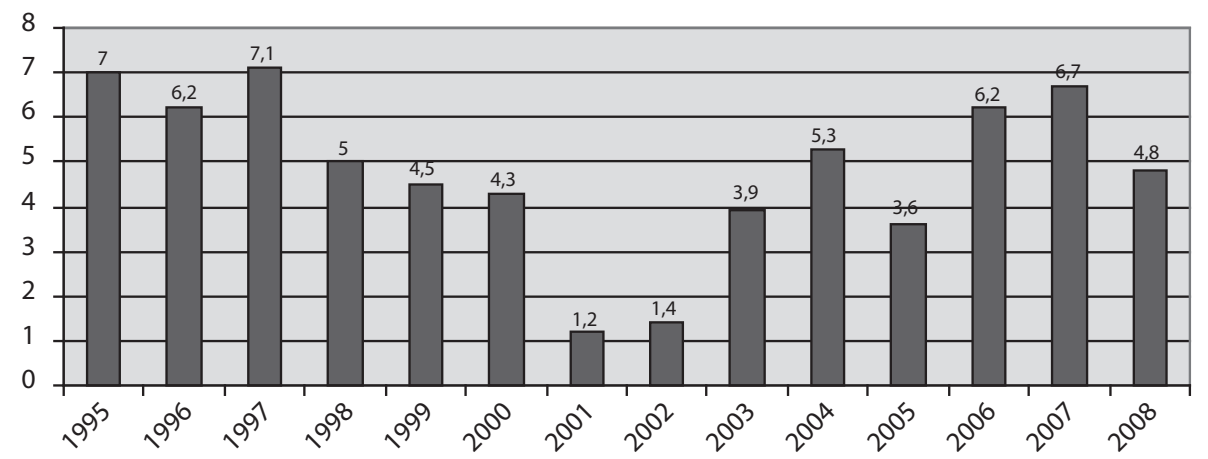

Source: The author's compilation based on data from GUS (Central Statistical Office of Poland).

Due to economic recovery, since 2002, the rate mentioned was higher than the average in EU-25 (1,9\%), but lower than that reached by new Member States from Central and Eastern Europe. A higher growth rate was achieved by, among others, Baltic countries (7-8\%) and an "old" EU country - Ireland (6\%). Generally, less developed countries reached in the analyzed period of time a higher growth rate, which means that there was a phenomenon of convergence in the European Union. ${ }^{15}$

At this point it seems relevant to compare the above data with the results reached by other national economies. The USA GDP per head measured by purchasing power parity was in $200851,6 \%$ higher than the average EU-27 rate, and 41,3\% higher than the average rate in EU-15. Of the EU countries, only Luxembourg had a bigger rate than the USA. Then, in Japan, the same rate in 2008 was 10,6\% better than the average EU-27 rate. However, in this case, as many as 10 EU Member States had a better rate than Japan, and one (Spain) was slightly weaker.

15 Compare: Raport o rozwoju i polityce regionalnej, Warszawa 2007, http://www.mrr. gov.pl/NR/rdonlyres/DFB16DC4-B970-464D-A347-73A2B3DF084A/44036/Raportorozwojuipolityceregionalnej.pdf, p. 14. 
For many years the Polish employment rate was also unfavourable. In comparison with the majority of present UE members, Poland's job market was the worst; while all countries, especially of the "old" EU had a stable growth of the workplace. ${ }^{16}$ Nevertheless, the situation on the job market has improved recently mainly thanks to new workplaces but also partly due to Polish intensive emigration abroad, and the unemployment rate has dropped to $9,5 \% .{ }^{17}$ Naturally, the present worldwide economic crisis has caused the increase in the number of people losing jobs or remaining unemployed in countries all over the world.

A factor contributing to modernization of economy is foreign investments. ${ }^{18}$ Over the past few years foreign investors became more visible in Poland and as a result, according to the situation at the end of 2007, a cumulative worth of direct foreign investments was 33\% of the Polish GDP and it was close to the average of EU-27. Of course, some of these investments just aim at entering a particular market not at further export (and at the same time improving the country's balance of payments). Still, there are definitely more positive aspects of such investments. Through such ventures, modern technologies and work organization are used in Poland more and more often, which influences the competitiveness of Polish enterprises, goods and services. ${ }^{19}$

Not only does the Polish economy have an unfavourable structure but also a relatively low level of innovation. The participation of expenses on research and development work in Poland decreased systematically and was in 2007 about $0,56 \%$ of GDP; by contrast, it was 1,83\% in EU-27.

16 Compare: Projekt Narodowej Strategii Rozwoju Regionalnego na lata 2007-2013, zaakceptowany przez Radę Ministrów w dniu 6 września 2005 roku, http://www.nsrr.gov. pl/NR/rdonlyres/F36C4DA8-A738-4BCA-BF37-45903AFDCACA/14584/nsrr_zwp72. pdf, p. 14.

17 GUS - General Statistical Office of Poland (data from the end of 2008): http:// www.stat.gov.pl/cps/rde/xbcr/gus/PUBL_PDL_bezrobocie_rejestrowane_I-IV_kw_2008. pdf.

18 In 2005, 8260 million euro of direct investments flew into Poland; in 2006, it was 15576 million euro; in 2007-17 196 million euro; in 2008-9 972 million euro, which makes Poland first among post-communist countries. The data come from Polish National Bank [in:] http://www.nbp.pl/publikacje/zib/zib2008.pdf, p. 15.

19 Compare: http://www.nbp.pl/publikacje/zib/ZIB2007n.pdf. 
Moreover, the innovation rate was lower than in the weakest developed countries of EU-15 and, what is more disturbing, lower than in countries which joined the EU with Poland (except for Slovakia). ${ }^{20}$ At the same time, there was a different structure of these expenses according to financing sources. In 2005, the last for which Eurostat has complete data, in Poland, the enterprise sector financed $33,4 \%$ of the research and technological development expenses, and the government sector - 57,7\%. In EU-27 this was $54,5 \%$ and $34,2 \%$ respectively. ${ }^{21}$ Low innovation is also proved by the fact that despite high export dynamics, the participation of high technology goods in export just slightly increased. In 2005, it was 3\% (2\% in 1995) and on average $18 \%$ in the EU in $2004 .{ }^{22}$ Such a situation makes decreasing tendencies in the number of inventions and utilitarian patterns as well as systematically deteriorating balance of payments in the field of trade exchange connected with science and technology achievements, ownership rights, license, trademarks and technical services. Besides, the expenses on the infrastructure and investment activity are still relatively low, despite the actual growth in past years. In this respect, Poland is a few per cent points behind some EU states..$^{23}$

20 In 2005, the innovation rate of enterprises in Poland was 0,21 versus the average 0,42 in EU-25, which placed Poland on the 21st position, [in:] European Innovation Scoreboard, Luxembourg 2005, p. 23. Compare: data concerning the research and development sector in Poland [in:] Strategia Rozwoju Kraju 2007-2015, Warszawa 2006, pp. $115-116$.

21 Compare: http://epp.eurostat.ec.europa.eu/tgm/refreshTableAction.do?tab=table \&plugin $=1$ \&init $=1$ \&pcode $=$ tsiir030\&language $=$ en .

22 Compare: Raport o rozwoju i polityce regionalnej, Warszawa 2007, http://www.mrr. gov.pl/NR/rdonlyres/DFB16DC4-B970-464D-A347-73A2B3DF084A/44036/Raportorozwojuipolityceregionalnej.pdf, p. 17.

23 Compare: Strategia Rozwoju Kraju 2007-2015, Warszawa 2006, pp. 9-24; Projekt Narodowej Strategii Rozwoju Regionalnego na lata 2007-2013, zaakceptowany przez Rade Ministrów w dniu 6 września 2005 roku, http://www.nsrr.gov.pl/NR/rdonlyres/F36C4DA8-A738-4BCA-BF37-45903AFDCACA/14584/nsrr_zwp72.pdf, p. 13. 
Table 2. Comparison of the EU Member States statistics concerning certain fields (2008)

\begin{tabular}{|c|c|c|c|c|c|c|}
\hline Country & 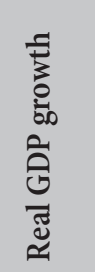 & 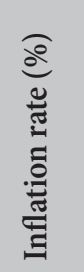 & 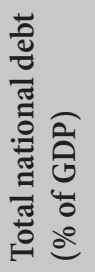 & 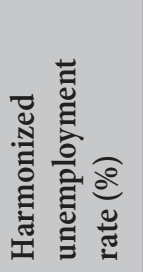 & 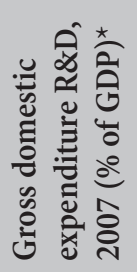 & 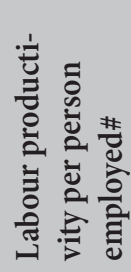 \\
\hline Austria & 1,8 & 3,2 & 62,5 & 4,2 & 2,36 & 114,5 \\
\hline Belgium & 1,2 & 4,5 & 89,6 & 6,8 & 1,87 & 127,9 \\
\hline Bulgaria & 6,0 & 12,0 & 14,1 & 5,3 & 0,48 & 36,2 \\
\hline Cyprus & 3,7 & 4,4 & 49,1 & 4,2 & 0,45 & 84,7 \\
\hline $\begin{array}{l}\text { Czech } \\
\text { Republic }\end{array}$ & 3,2 & 6,3 & 29,8 & 4,6 & 1,54 & 72,2 \\
\hline Denmark & $-1,1$ & 3,6 & 33,3 & 4,1 & 2,55 & 100,7 \\
\hline Estonia & $-3,6$ & 10,6 & 4,8 & 8,4 & 1,14 & 61,0 \\
\hline Finland & 0,9 & 3,9 & 33,4 & 6,6 & 3,47 & 109,6 \\
\hline France & - & 3,2 & 68,0 & 8,3 & 2,08 & - \\
\hline Greece & 2,9 & 4,2 & 97,6 & 7,8 & 0,57 & 103,4 \\
\hline Spain & 1,2 & 4,1 & 39,5 & 14,3 & 1,27 & 105,2 \\
\hline Netherlands & 2,1 & 2,2 & 58,2 & 2,7 & - & 114,4 \\
\hline Ireland & $-2,3$ & 3,1 & 43,2 & 8,7 & 1,31 & 138,3 \\
\hline Lithuania & 3,0 & 11,1 & 15,6 & 9,7 & 0,82 & 60,8 \\
\hline Luxembourg & $-0,9$ & 4,1 & 14,7 & 5,5 & 1,63 & 166,4 \\
\hline Latvia & $-4,6$ & 15,3 & 19,5 & 11,4 & 0,63 & 50,8 \\
\hline Malta & 2,7 & 4,7 & 64,1 & 6,0 & 0,60 & 90,7 \\
\hline Germany & 1,3 & 2,8 & 65,9 & 7,2 & 2,53 & 107,2 \\
\hline Poland & 4,8 & 4,2 & 47,1 & 7,0 & 0,56 & 61,2 \\
\hline Portugal & 0,0 & 2,7 & 66,4 & 8,0 & 1,18 & 70,7 \\
\hline Romania & 7,1 & 7,9 & 13,6 & 5,8 & 0,53 & 46,1 \\
\hline Slovakia & 6,4 & 3,9 & 27,6 & 9,2 & 0,46 & 77,1 \\
\hline Slovenia & 3,5 & 5,5 & 22,8 & 4,1 & 1,53 & 84,9 \\
\hline Sweden & $-0,2$ & 3,3 & 38,0 & 7,0 & 3,64 & 113,0 \\
\hline
\end{tabular}




\begin{tabular}{|c|c|c|c|c|c|c|}
\hline Country & 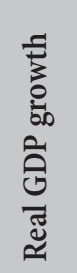 & 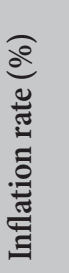 & 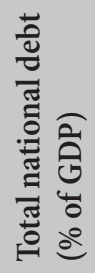 & 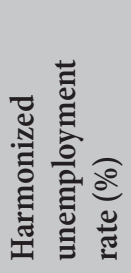 & 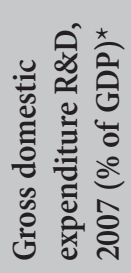 & 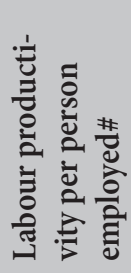 \\
\hline Hungary & 0,5 & 6,0 & 73,0 & 8,4 & 0,97 & 72,9 \\
\hline Great Britain & 0,7 & 3,6 & 52,0 & 6,4 & - & 112,3 \\
\hline Spain & $-1,0$ & 3,5 & 105,8 & 6,9 & - & 106,6 \\
\hline EU-15 & 0,7 & - & - & 7,8 & 1,91 & 109,2 \\
\hline EU-25 & 0,8 & - & 62,2 & 7,7 & - & 103,7 \\
\hline EU-27 & 0,9 & 3,7 & 61,5 & 7,6 & 1,83 & 100,0 \\
\hline Euro Area & 0,8 & 3,3 & 69,6 & 8,1 & 1,86 & - \\
\hline
\end{tabular}

* estimated data

\# predictions

Source: Growing Regions, growing Europe. Fourth report on economic and social cohesion, Luxembourg 2007, p. 118 and websites of Eurostat. ${ }^{24}$

The analysis of Poland's development over past few years, in comparison with other EU states, shows that the dynamics of reducing the developmental gap to the "old" EU countries has been relatively small. Up to 2003, it mainly resulted from the increase in management effectiveness which was achieved by employment reduction and thus led to a deteriorating situation on the job market. However, one must emphasize the importance of huge quality changes that appeared in the economy structure of the 1990s, which contributed to a significant growth of productivity. ${ }^{25}$

${ }^{24}$ Eurostat: http://epp.eurostat.ec.europa.eu/tgm/table.do?tab=table\&init=1\&plugi $\mathrm{n}=1$ \&language $=$ en \&pcode $=$ tsieb020; http://epp.eurostat.ec.europa.eu/tgm/table.do?tab $=$ table\&language $=$ en $\&$ pcode $=$ tsieb060\&tableSelection $=1 \&$ footnotes $=$ yes\&labeling $=$ lab els\&plugin=1; http://epp.eurostat.ec.europa.eu/tgm/table.do?tab=table\&init=1\&langu age $=$ en \&pcode=tsieb090; http://epp.eurostat.ec.europa.eu/tgm/table.do?tab=table\&lan guage $=$ en $\&$ pcode $=$ teilm020\&tableSelection $=1 \&$ plugin $=1 ;$ http://epp.eurostat.ec.europa . $\mathrm{eu} / \mathrm{tgm} /$ table.do?tab=table\&init=1\&plugin=1\&language=en\&pcode=tsiir020; http://epp . eurostat.ec.europa.eu/tgm/table.do?tab=table\&init $=1 \&$ language $=$ en $\&$ pcode $=$ tsieb030 \& plugin $=0$.

25 Compare: Raport o rozwoju i polityce regionalnej, Warszawa 2007, http://www.mrr. gov.pl/NR/rdonlyres/DFB16DC4-B970-464D-A347-73A2B3DF084A/44036/Raporto- 


\section{SOCIO-ECONOMIC SITUATION OF PARTICULAR POLISH VOIVODSHIPS IN COMPARISON WITH OTHER EU REGIONS}

At this point, it is worth considering the issue of developmental distance between Polish voivodships and other EU regions. The Eurostat ${ }^{26}$ statistics are very useful in this respect. A bad situation of Polish voivoidships is best demonstrated by the fact that among 15 richest regions of the EU-27 (for example, Inner London, Luxembourg, Région de Bruxelles-Capitale/ Brussels Hoofdstedelijk Gewest) there is not a single Polish voivodship. By contrast, among the poorest 15 regions there are as many as three (Lubelskie, Podkarpackie, Podlaskie).27 In these voivodships, the GDP per citizen is considerably lower than the one that could be observed in the poorest regions of Greece, Spain and Portugal when they joined the EU. For instance, GDP per head in the weakest region of Greece (Voreio Aigaio) was 44\% in 1981, of Spain (Extremadura) - 44\% and of Portugal (Alentejo) - 37\% in the year of $1986 .{ }^{28}$

By contrast, in the three previously mentioned least developed Polish voivodships, the GDP per citizen in 2004, despite the pre-accession financial help, was: Lubelskie - 35,1\%, Podkarpackie - 35,3\%, Podlaskie - 37,8\% respectively. It must be also added that the level of the development of Polish richest voivodship (Mazowieckie), which was measured in the same way, was just $77,1 \%$ of the EU-27 average and was $258 \%{ }^{29}$ lower than the

rozwojuipolityceregionalnej.pdf, pp. 19-20.

26 To meet the requirements of statistical analyses, the institution has prepared, based on the number of population, the network of 268 regions at the level of NUTS II (equivalents of Polish voivodships).

27 Compare: Eurostat News Release, 19 February 2007, http://epp.eurostat.ec.europa. eu/pls/portal/docs/PAGE/PGP_PRD_CAT_PREREL/PGE_CAT_PREREL_YEAR_2007/ PGE_CAT_PREREL_YEAR_2007_MONTH_02/1-19022007-EN-AP.PDF, p. 2.

28 Por.: Raport o polityce regionalnej, Warszawa 2004, pp. 38-55; Projekt Narodowej Strategii Rozwoju Regionalnego na lata 2007-2013, zaakceptowany przez Radę Ministrów $w$ dniu 6 września 2005 roku, http://www.nsrr.gov.pl/NR/rdonlyres/F36C4DA8A738-4BCA-BF37-45903AFDCACA/14584/nsrr_zwp72.pdf, p. 19.

29 Eurostat: http://epp.eurostat.ec.europa.eu/tgm/table.do?tab=table\&init=1\&langu age $=$ en $\&$ pode $=\operatorname{tgs} 00006$. 
richest region of NUTS II level (Inner London). One can draw a conclusion that the level of the development of Polish strongest voivodship is currently (year $2006-83,6 \%$, the lack of more recent data) is close to the level of the development of poor regions of the "old" EU in Greece, Spain or Portugal.

Table 3. Regions with GDP

per head $<75 \%$ below of EU average, 1995 and 2004

\begin{tabular}{|l|c|c|c|c|c|c|c|}
\hline \multirow{2}{*}{} & \multicolumn{2}{|c|}{ UE-15 } & \multicolumn{2}{c|}{$\begin{array}{c}\text { New Mem- } \\
\text { ber States }\end{array}$} & \multicolumn{2}{c|}{ UE-27 } \\
\cline { 2 - 8 } & 1995 & 2004 & 1995 & 2004 & 1995 & 2004 \\
\hline Number of regions in the EU & \multicolumn{2}{|c|}{213} & \multicolumn{2}{|c|}{55} & \multicolumn{2}{|c|}{268} \\
\hline EU total population (million) & 372 & 386 & 106 & 104 & 479 & 490 \\
\hline $\begin{array}{l}\text { Regions number with GDP <75\% below } \\
\text { EU average }\end{array}$ & 27 & 21 & 51 & 49 & 78 & 70 \\
\hline $\begin{array}{l}\text { The population of regions with GDP } \\
<75 \% \text { below EU average (million) }\end{array}$ & 32 & 32 & 103 & 91 & 136 & 123 \\
\hline $\begin{array}{l}\text { The population of regions with GDP } \\
<75 \% \text { below EU average (\%) }\end{array}$ & 9 & 8 & 97 & 88 & 28 & 25 \\
\hline
\end{tabular}

Source: Growing Regions, growing Europe. Fourth report on economic and social cohesion, Luxembourg 2007, p. 33.

It is also worth considering the issue of EU regions' development over the last few years. In 1995, 78 out of 268 NUTS II level regions, which are now the EU-27 members, had the GDP rate per head 75\% lower than the EU-27 average. Of those 78 regions, as many as 51 were from the new EU Member States and only 27 from the "old" EU countries. 39 out of those 51 regions in the new EU Member States had GDP per citizen below 50\% of EU average. Only four regions in the new Member States had GDP rate more than $75 \%$ of EU average: Prague, Cyprus, Malta and Bratislava. In 2004 , as the statistics show, the situation improved. The number of regions with GDP per head lower than $75 \%$ of EU average dropped to 70 (49 in new Member States and 21 in "old" EU countries. The regions that crossed the threshold of EU average were Slovenia and two regions with countries' 
capital cities: Mazowieckie and Közép-Magyarország - Hungary). In the same period of time, the number of regions with GDP per head below $50 \%$ of EU average dropped from 39 to 32. Besides, in the "old" EU States, three Italian regions (Campagnia, Puglia and Sicily) dropped below 75\% of EU average, and 9 crossed this threshold (one in Ireland, Germany and Great Britain; two in Greece; four in Spain). ${ }^{30}$

However, the fact that Polish voivodships have faster economic growth and there is an outside convergence does not mean that the continuation of the current development policy will bring positive results also in the future. One has to remember that with a progressing socio-economic development of Poland and reaching civilization standards of so far best developed European Areas, there is "a move in the centre of gravity from the equalizing of chances to creating competitive and innovative regions." ${ }^{31}$ As a result, the development of Polish voivodships, and especially the level of their competitiveness, will depend to a bigger and bigger extent on their innovation potential as well as the ability to activate various mechanisms of innovation diffusion and technology transfer. ${ }^{32}$

In comparison with other European countries, the inner differentiation of the development of Polish regions is not high. While in Poland the relation between the richest and the poorest region at the NUTS II level was 2,18 in 2004; it was above 3 in Belgium, France, Slovakia and Great Britain and even higher in Czech Republic, Romania and Hungary. The lowest $(1,56)$ was in Ireland, ${ }^{33}$ and lower than 2 - in Finland, the Netherlands and Sweden. In the year of 2005, this data changed: this proportion

30 Compare: Growing Regions, growing Europe. Fourth report on economic and social cohesion, Luxembourg 2007, p. 31.

31 M.E. Sokołowicz, W kierunku nowej polityki regionalnej? Rozważania nad przyszłym kształtem polityki regionalnej w Polsce, [in:] Polityka spójności - ocena i wyzwania. Materiały z konferencji, Warszawa 2008, p. 19.

32 Compare: A. Nowakowska, M.E. Sokołowicz, Zdolności innowacyjne polskich regionów, [in:] Innowacje i przedsiębiorczość dla przyszłości, Wrocław 2006, p. 76.

33 There are only two NUTS II regions there. This comparison does not include small countries where there is no division at such a level. (Cyprus, Denmark, Estonia, Lithuania, Luxembourg, Latvia, Malta and Slovenia). 
for Poland was 2,32; and 7 countries $^{34}$ had a worse result. The biggest disproportions among NUTS II regions were observed in Great Britain $(3,91)$, Slovakia $(3,91)$ and France $(3,41)$. On the other hand, the best in this respect was once again Ireland $(1,51)$ followed by Finland and Sweden (both 1,63$)$ and the Netherlands $(1,64)$.

\section{FINAL REMARKS}

In the 21st century various worldwide trends such as globalization, economic co-dependence or increasing competition make different countries face challenges, the challenges they are not and will not be able to meet on their own. Therefore, a very important phenomenon in international relations, yet of a different nature, are integration processes of the $\mathrm{EU}$. This is due to the influence these processes have on socio-economic shape of Europe and on international relations in a political aspect.

In the history of this part of the world, the day of May 1, 2004 should be considered remarkable. Then, Poland and nine other countries joined the European Union and contributed to the beginning of Europe's new shape closing the era of the continent's division at the same time. For the majority of the new Member States, this event symbolically crowned their efforts with success. The efforts that aimed at a guarantee of foreign security, democracy reinforcement as well as re-joining in the common trend of European tradition, policy and economy.

The EU enlargement up to 25 (then 27) countries, which took place just 12 or so years after the fall of communism in Europe, was possible thanks to, among many, the fact that in the financial prospects for 2000-2006, for the first time in the history of European integration, it was decided to provide help for the EU candidate-countries in their adaptive processes. The

34 Belgium(3,02), Czech Republic $(2,68)$, France $(3,41)$, Germany $(2,72)$, Slovakia(3,43), Romania $(3,09)$ and Great Britain $(3,91)$. Compare: http://epp.eurostat.ec. europa.eu/extraction/retrieve/en/theme1/reg/reg_e2gdp?OutputDir=EJOutputDir_11 29\&user=unknown\&clientsessionid=AE1AACA97343464BF53B1061A3ACAEC8.extraction-worker-2\&OutputFile=reg_e2gdp.htm\&OutputMode $=$ U \&NumberOfCells $=47$ $7 \&$ Language $=$ en $\&$ OutputMime $=$ text $\% 2$ Fhtml $\&$. 
main stimuli of these processes were so called pre-accession funds: PHARE, ISPA and SAPARD, which were a form of non-returnable help programme for all EU candidates. They were a kind of school enabling those countries to learn the procedures and mechanisms of the EU, bearing in mind their future joining this organization and participation in the structural funds.

One has to remember that each EU enlargement has had a smaller influence on the inner cohesion of the Communities, now the European Union. The participants of the integration processes have included the countries deviating from the previous Member States by the level of socioeconomic development. On 1 May 2004, the EU was enlarged by ten countries, including Poland. As it was the biggest enlargement in its history, it must have influenced institutions, policies and economy of this organization.

Despite the progressing outer convergence, it can be stated that, with the exception of a few big cities and just few areas attractive in terms of tourism and agriculture, all Polish voivodships are threatened by the peripheralization in the integrating Europe. Such processes are especially visible in the eastern parts of Poland. A typical way of thinking where the EU is supposed to eliminate the risk of marginalization of the Polish regions implies another danger. It consists in being dependent on the outer help, no matter what the ability to implement the received financial support is. Thus, the actions on different levels must be taken not only to decrease the above-mentioned dangers of marginalization but also to facilitate better conditions for a further development of the regions. ${ }^{35}$

Undoubtedly, a factor favouring a development of voivodships and sub-regions is rising their economic attractiveness and competitiveness. In the aspect of Poland's membership in the European Union, this means a further implementation of the Lisbon Strategy recommendations and

35 "These actions should take into consideration new mechanisms of development, especially new criteria of localization, basing the development on endogenic factors and strategies of building competitive economy, supporting institutional effectiveness of public administration as well as building network and cooperation links between institutions of regional development", [in:] Założenia Narodowej Strategii Rozwoju Regionalnego na lata 2007-2013, http://www.nsrr.gov.pl/NR/rdonlyres/DA09CB61-6BC8-49B1-862FD03E1D57EE75/0/zalozeniansrr.pdf, p. 19. 
the pursuit of creating knowledge-based economy. The policy of Poland's development in the years 2000-2006 was characterized by interventions directed at equalizing aims - consisting in prevention of further marginalization of some regions. The aims directed at rising the competitiveness of voivodships were less important. However, taking such expenses into consideration should be the result of not only a formal requirement of the EU but also a real necessity to stimulate the processes of the country's development. It has to be emphasized that "appropriate connection of the elements of both policies in the sphere of strategic assumptions, the instruments of their realization and implementation mechanisms will create the conditions for effective stimulation of processes constituting a permanent and balanced development." 36

One has to admit that in their development strategies, all Polish voivodships have included the need to invest in innovative economy by means of expenses planned for these aims in the Regional Operational Programmes (on an average over $30 \%$ ). Such a situation raises a question: to what degree - bearing in mind the basic infrastructure that is not developed enough - can the funds available be raised for the development of innovation in its wide understanding? Bigger expenses on competitiveness are definitely needed to catch up on civilization development. It is hard to imagine a further development of the country (its voivodships), though, without first high expenses connected with creating basic infrastructure. Therefore, it seems that in Poland, an optimal model of development policy will still be a combination of cohesion and knowledge-based economy actions together with the emphasis on the increase of the importance of competitiveness at the expense of convergence.

36 Example actions: a) supporting innovation and R\&D; b) developing regional potential of financial and consulting institutions; c) creating a transfer network of innovation and technology; d) creating conditions for education and science development; e) developing enterprise; f) eliminating metropolis developmental barriers, etc. 